\title{
OBSTERTOS.
}

\section{UNDER THE CHARGE OF}

\author{
EDWARD P. DAVIS, A.M., M.D., \\ PROPESSOR OF OHFTETHIC AMD DERASES OP INFAYCY IN TEE PHLLDELPHIA FOLYCLNIC ; \\ CLINICAI PAOPESSOR OP OBTETRTCS IN THE JEFFERSON MEDICAE COLLEOE; CLIICAL \\ PROFRESOH OP DIREASES OP CTILDREN IN THE WOANA'S MEDECAL COLLEGE; \\ VISITINo OESTETRKCLN TO THE PHTLADELPHA HOSPTLA, ETC.; \\ Agaigten ay \\ Willtak H. WELLs, M.D.,

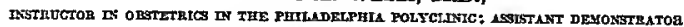 \\ OF OASTERRTCS IN THE JEFFERON MEDICAL COLLEGE.
}

\section{a Case of Air-Earonos in Placenta Przvila.}

HEUcK (Zeitschrift für Geburtshülfe und Gynäkologie, Bd. xxviii., H. 1) describes a case of oir-emholus with fatal termination in a cass of placenta previo. The patient was admitted in lahor, ond the dirgnosis of placenta pravia estahlished. Under narcosis version was ottempted, ond a foot seized and hrought down to the vulva. As soon as this occurred the woman had a violent pain and hore down hard; nt the same time a thick stream of hloody woter spurted from the ragina. She was hrought lengthwise to the hed, when suddeoly the pulse hecame imperceptihle and the face slightly cyanotic. Breathiog persisted, hut less frequently than normol. Injectioos of camphorated ether were given, the chin depressed, and artificial regpiration practised, but all in vain. The respiration hecame less nnd less frequent, marked cyanosis ensued, and death followed in ahout five minutes. At the autopsy, two hours post-mortem, on section of the right jugular vein, an air-huhble as large as a hazel-nut eseaped. The great vessels of the heart were tied. The heart gave a tympanitic note, and on lifting it up one could see clearly through the thin walls of the right ventricle air-buhbles rising from deep within the heort. The right heart was opeoed under water, when air-hubbles escaped from it. The coronary arteries contnined no air, and the heart's musculature and valves were normol. Lungs and pleure were sound. Air-huhhles were also found in the right spermatic (ovarian) vein. The unopened uterus was placed in alcohol and opened some weeks loter. It contained a placenta prævin centralis, the principal part attached to the right and posterior wall. It was partially detached on the right side, hut no large vessel-lumina were observed. The outhor concludes that it is improhahle under the manipulations of version that air was pressed into the reins, hut helieves that this took place immediately after the version was complete. At the moment when the foot hng from the vagina o violeot prin and gush of hloody water occurred, and immediately the radial pulse failed, while respiration persisted. It is helieved that at this moment the air hetween the uterine wall and the detached surface of the placenta was pressed into the gaping lnmins of the veins. Further, this air was, hy the sudden lowering of ahdominal pressure due to cessation of pain and hearing down, aspirated 
into the spermatic (ovarian) vein, and thence into the vens cava and right heart. Three cases in the last six yess occurring in this clinic (Universitäts Franenklinik, Berlin) ehow that this nccident is not so rare as many imagine.

\section{The Histozogy of the Huaran amnion and Carbiutcat Cord.}

LANGE (Zeitsehr. für Gebürtshulfe und Gynäkologie, Bd. xxviii., H. 1) presents a contribution to the histological anntomy of the amnion and umbilical cord in the homan emhryo. His conclusions are as follows:

1. The epithelium of the amnion is not cuhical or cylindrical, hut a single layer of parement epithelium.

2. The granulation of the dead amniotic epithelium does not depend on the presence of fat.

3. In the amniotic epithelinm there are no open mouths of lymph passages. The pretended stomata are artificial, and arise through the rupture of degenerated mucons cells.

4. The umbilical epithelium ie, as n rule, a three-, seldom four- or fivelayered laminated epithelium, whose deep layer consists only of flat cells.

5. During emhryonic life the differentiation into a laminated epithelium appears on the umbilical cord earlier then the division of the epithelium.

6. "Stomata" are not fonnd in the epithelinm of the nmhilical cord.

7. The umbilical cord of a mature fetus contains numerous elastic fihres within the connective tissue.

8. The cord contains no other lymph channels than the connective-tissue corpuscles of Virchow.

9. These capillary lymph channels are most prohahly susceptihle of injection.

10. Between the epithelial cells of the cord can he found no hranches of lymph channele.

\section{axatomy and Physlology of the Craculation of the Netrorn.}

StrassmanN (Archiv für Gynäkologie, Bd. xlv., H. 3) gives the results of his investigations concerning the anatomy and physiology of the circulation in the newhorn. Briefly these may he tahulated as follows:

1. The explnnations heretofore accepted 29 to the cause of the closure of the ductus arteriosus are not satisfactory :

a. Thrombosis is eeldom found, and is pathological.

b. Self-clogure hy contraction of the duct is not demonstrated.

c. Changes of position of the thoracic organs with hending of the duct after inspiration has no anntomical hasis.

$d$. The post-partum changes in the dnct walls are neither peculiar nor characteristic, as they also occur in the umhilical ressels.

e. The impulses mentioned in $b$ and $d$ faror the definitive ohliteration of the duct.

2. The closure of the dnct comes instantly and mechanically.

3. The manner of entrance of the duct into the aorta makes possihle snch mechanical closure.

4. From the fifth month in the human fotus a progressive devclopment of voL. 108, พ0. 5-TOVEXrEER, 1894. 